\title{
Macronutrient composition of nickel-treated wheat under different sulfur concentrations in the nutrient solution
}

\author{
Renata Matraszek $^{1} \cdot$ Barbara Hawrylak-Nowak $^{1} \cdot$ Stanislaw Chwil $^{2} \cdot$ Miroslawa Chwil $^{3}$
}

Received: 21 July 2015 / Accepted: 16 November 2015 / Published online: 23 November 2015

(C) The Author(s) 2015. This article is published with open access at Springerlink.com

\begin{abstract}
The effect of different sulfate(VI) sulfur (2, 6, and $9 \mathrm{mM} \mathrm{S})$ levels and nickel(II) chloride (0, 0.0004, 0.04 and $0.08 \mathrm{mM} \mathrm{Ni}$ ) in the nutrient solution on productivity and macronutrient $(\mathrm{N}, \mathrm{P}, \mathrm{K}, \mathrm{Ca}, \mathrm{Mg}, \mathrm{S})$ status and accumulation in spring wheat (Triticum aestivum L.) Zebra cv. was studied. $\mathrm{Ni}$ treatment reduced the biomass and disturbed the balance and accumulation of macronutrients in wheat. Intensive $\mathrm{S} \mathrm{nu}-$ trition, especially with $6 \mathrm{mM} \mathrm{S}$, at least partially increased the biomass, improved ionic equilibrium, and enhanced nutrient accumulation in $\mathrm{Ni}$-exposed plants in spite of increased $\mathrm{Ni}$ accumulation. Admittedly, the dose $9 \mathrm{mM} \mathrm{S}$ reduced $\mathrm{Ni}$ accumulation in shoots but increased accumulation thereof in roots. Compared to $6 \mathrm{mM}$, the dose $9 \mathrm{mM}$ was less effective in improving the mineral status of Ni-treated wheat.
\end{abstract}

Keywords Macronutrient content $\cdot$ Nickel stress $\cdot$ Sulfur nutrition · Wheat (Triticum aestivum $\mathrm{L}$.)

Responsible editor: Philippe Garrigues

Renata Matraszek

renata.matraszek@up.lublin.pl

Barbara Hawrylak-Nowak

bhawrylak@yahoo.com

Stanisław Chwil

stanislaw.chwil@up.lublin.pl

Mirosława Chwil

miroslawa.chwil@up.lublin.pl

1 Department of Plant Physiology, University of Life Sciences in Lublin, Akademicka 15, 20-950 Lublin, Poland

2 Department of Agricultural and Environmental Chemistry, University of Life Sciences in Lublin, Akademicka 15, 20-950 Lublin, Poland

3 Department of Botany, University of Life Sciences in Lublin, Akademicka 15, 20-950 Lublin, Poland

\section{Introduction}

Nickel (Ni) is recognized as a heavy metal micronutrient required for proper plant growth and development (Chen et al. 2009; da Silva et al. 2012a, b; Mazzafera et al. 2013). The Ni requirement of plants, which is below $0.5 \mathrm{mg} \mathrm{kg}^{-1}$ dry weight (DW), is the lowest of all essential elements (Liu et al. 2011; López and Magnitski 2011). Ni is a functional constituent of some enzymes inter alia urease (Sigel et al. 2007; Ragsdale 2009). The metabolism of this element is crucial for maintaining a proper cellular redox state and various other biochemical, physiological, and growth responses. Besides involvement in nitrogen $(\mathrm{N})$ metabolism and iron absorption, $\mathrm{Ni}$ is required for viable seed production and germination (Brown 2007; Ahmad and Ashraf 2011; Poonkothai and Vijayavathi 2012).

During the last few decades, a significant increase in environmental contamination with $\mathrm{Ni}$ has been observed; hence, a phytotoxic effect of this element, rather than deficiency, is much more commonly found. The increasing Ni pollution of the environment is mainly caused by various anthropogenic activities: fossil fuel combustion, metal (especially $\mathrm{Ni}$ ) ore mining, smelting and refining, metallurgical and electroplating industry, cement and steel manufacturing, municipal refuse incineration, electrical and electronic industry, chemical and food industry, agricultural use of sewage sludge, application of organic and mineral fertilizers, and many others (Cempel and Nikel 2006; Iyaka 2011; Wuana and Okieimen 2011; Yusuf et al. 2011). Ni pollution has become a serious concern. It is estimated that concentrations of this metal in polluted soils, surface waters, and air have reached up to 26 , $000 \mathrm{mg} \mathrm{kg}^{-1} ; 0.2 \mathrm{mg} \mathrm{L}^{-1}$; and $2000 \mathrm{ng} \mathrm{m}^{-3}$, respectively, which is 20-30 times higher than those found in unpolluted areas (Kabata-Pendias and Mukherjee 2007). The maximum permissible Ni concentration in agricultural soil according to 
the standards set by United Nations Economic Commissions for Europe (UNECE) is $100 \mathrm{mg} \mathrm{kg}^{-1}$ and in ground water, $20 \mathrm{~g} \mathrm{~L} \mathrm{~L}^{-1}$ (Gaillardet et al. 2005; Nazir et al. 2015). Soil clean-up target levels (SCTLs) have been determined to be 100 and $28,000 \mathrm{~g} \mathrm{~L}^{-1}$ for residential considerations and commercial sites, respectively (Lander 2003). Ni moves through the environment very easily and is readily taken up by plants. Excessive concentrations of this element are phytotoxic and lead to severe growth inhibition and limited biomass production. The toxic Ni content in plants varies in relation to the degree of sensitivity or tolerance to the metal. It is assumed that a critical toxicity $\mathrm{Ni}$ level in sensitive, moderately tolerant, and tolerant species is 10,50 , and $100 \mathrm{mg} \mathrm{kg}^{-1}$ dry mass (DM), respectively (Kozlow 2005; Yusuf et al. 2011; Hussain et al. 2013). In hyperaccumulators (genus Alyssum and Thlaspi), the toxic Ni content exceeds $1000 \mathrm{mg} \mathrm{kg}^{-1} \mathrm{DM}$ (Küpper et al. 2001; Pollard et al. 2002; Yusuf et al. 2011; Leitenmaier and Küpper 2013). The toxicity of Ni has become a worldwide problem threatening sustainable agriculture (Aydinalp and Marinova 2003; Kucharski et al. 2009). Cereals (especially oat) are recognized as very sensitive to $\mathrm{Ni}$, whereas legumes and members of the mustard family can tolerate and accumulate high amounts of this element. There is little information about Ni toxicity mechanisms in plants, compared to other toxic trace metals like lead $(\mathrm{Pb})$, cadmium $(\mathrm{Cd})$, copper $(\mathrm{Cu})$, and chromium $(\mathrm{Cr})$. This is due to the dual character and complex electronic chemistry of this metal, which makes it difficult to study its biological role and toxicity (Kabata-Pendias and Mukherjee 2007; Yusuf et al. 2011). Toxic effects of $\mathrm{Ni}$ are observed at multiple levels. One of them is disrupting the nutritional status of plants. $\mathrm{Ni}$ interferes with uptake, transport, and distribution of elements of macro- and micronutrients. Literature data show a contradictory effect of $\mathrm{Ni}$ on plant mineral nutrition. The contents of mineral nutrients in organs of Ni-treated plants may drop, rise, or remain unchanged (Sreekanth et al. 2013). However, although there are many reports concerning the phytotoxic effects and tolerance to $\mathrm{Ni}$, our knowledge in this area is still incomplete, and the detailed mechanisms involved are poorly understood.

Sulfur (S) is a macronutrient receiving special attention in soil science and plant nutrition. This element is involved not only in proper growth and development, but is also associated with biotic and abiotic stress tolerance in higher plants (Starast et al. 2007). The requirement of plants for this element ranges from about 0.1 to $1.0 \%$ (on a dry weight basis). Wheat, the biological object of our investigations, is a species characterized by low requirements for sulfur (Droux 2004; Zagorchev et al. 2013). Together with nitrogen, sulfur is assimilated by plants in redox processes and forms part of carbohydrate compounds. Nowadays, progressive process of reducing emissions of $\mathrm{S}$ to the natural environment is observed. $\mathrm{N}$ and $\mathrm{P}$ fertilizers without $\mathrm{S}$ are much more frequently used than those containing S. Sulfate ions easily leach deeper into the soil profile and they are relatively immobile in the soil-plant system. All of the above-mentioned reasons limit S availability to plants and cause its deficiency and reduction of crop yield and quality (Mašauskiene and Mašauskas 2012). According to biochemical function, $\mathrm{S}$, together with $\mathrm{N}$, is classified as a nutrient forming the organic compounds of plants. $\mathrm{S}$ serves many functions in plants. This element is used in the formation of amino acids (cysteine (Cys), cystine (Cys) 2 , and methionine (Met)); peptides; proteins; lipoic acid (LA); essential oils (adenosine 5 -phosphosulfate (AMPS)); and glucosinolate (3 -phosphoadenosine-5 -phosphosulfate (PAPS)) and is known as a universal $\mathrm{S}$ donor for sulfotransferases, or it is a structural component of these compounds. $\mathrm{S}$ is active in the conversion of inorganic $\mathrm{N}$ into protein. This element catalyzes chlorophyll formation. It promotes nodulation in legumes, helps develop and activate various enzymes, coenzymes, and vitamins (biotin, thiamin, coenzyme A (CoA)), and is their component. Ligands containing sulfhydryl ( $\mathrm{SH})$ groups, i.e., glutathione (GSH) or phytochelatins (PCs), form high-strength, durable complexes with heavy metals. It is claimed that especially the former compound plays an important role in Ni resistance (Bhatia et al. 2005; Hawkesford and De Kok 2006; Kopriva 2007; Khan et al. 2008; Gill and Tuteja 2011; Mazid et al. 2011a, b; Hossain et al. 2012; Viehweger 2014).

Given the fact that Ni, like most heavy metals, interferes with the uptake and transport of many essential nutrients including sulfur as well as taking into account the role of S in building resistance to stress caused by the presence of heavy metals, these studies were undertaken to assess the effect of intensive $\mathrm{S}-\mathrm{SO}_{4}{ }^{2-}$ nutrition on the mineral composition of Nitreated wheat (Triticum aestivum L.). This species is a very important agricultural crop showing a low demand for $\mathrm{S}$. The results presented in this paper are only part of a research project concerning the role of intensive $\mathrm{S}$ nutrition in mechanisms of tolerance to Ni. We hope that our investigations will help to understand and develop strategies for alleviation of Ni phytotoxicity with additional sulfur fertilization.

\section{Materials and methods}

\section{Plant material characteristics and growth conditions}

The experiment was carried out in 2011-2014 in the Plant Physiology Department, University of Life Sciences in Lublin, Poland. The biological object of the study was spring wheat (Triticum aestivum L.), family Poaceae. For the experiment, an elite highly fertile Swedish bread cultivar Zebra (Firm SVALOV WEIBULL) with superior baking quality and high tolerance to pathogens, except for leaf rust (Puccinia recondita Rob. ex Desm. f. sp. tritici (Eriks.) 
Jonson), was chosen. The examined cultivar Zebra was included into the Polish National List in COBORU in 2000 (Polish National List of Agricultural Plant Varieties 2012). Plants of this cultivar are medium in height with a very good lodging resistance and quite an early deadline of heading and ripening. The grain of this variety is medium-sized with average alignment. It contains high levels of best-quality protein and gluten. The offal content is very low. "Zebra" is a variety with moderate soil requirements and much better resistance to drought than other cultivars. A factor significantly limiting yielding of this cultivar is low $\mathrm{pH}$.

The experiment was carried out with the method of water cultures. One-week-old seedlings were transferred to $1 \mathrm{dm}^{3}$ glass jars (two plants each) with Hoagland's II solution. The differentiating factors of the experiment were the sulfur level=2.00 (control, basic, or standard dose), 6.00 , and $9.00 \mathrm{mM}$ and nickel concentration $\left(\mathrm{NiCl}_{2}\right)=0$, $0.0004,0.04$, and $0.08 \mathrm{mM}$. The standard sulfur dose (2 mM) was supplied as $\mathrm{MgSO}_{4}$, while in the treatment with high $\mathrm{S}$ doses, i.e., 6 and $9 \mathrm{mM} \mathrm{S}$, a standard sulfur dose in the $\mathrm{MgSO}_{4}$ form was additionally supplemented with appropriate amounts of $\mathrm{Na}_{2} \mathrm{SO}_{4}$. In all experimental treatments, the level of sodium $(\mathrm{Na})$ and chlorine $(\mathrm{Cl})$ was equalized by adding appropriate amounts of $1 \% \mathrm{NaCl}$ and $\mathrm{HCl}$ to the nutrient solution; the $\mathrm{pH}$ of the nutritional environment was set at 5.8-6.0. Plant vegetation was conducted in a phytotron under controlled conditions: 25:20 ${ }^{\circ} \mathrm{C}$ day/night temperature, $14: 10 \mathrm{~h}$ photoperiod, photosynthetic photon flux density (PPFD) $400 \pm$ $10 \mu \mathrm{mol} \mathrm{m} \mathrm{m}^{-2} \mathrm{~s}^{-1}$, and relative air humidity between 60 and $70 \%$. After 2 weeks of growth under conditions of different Ni contamination and $\mathrm{S}$ nutrition, plants were harvested and dry mass (DM) as well as the macronutrient composition of roots and shoots (total nitrogen $(\mathrm{N})$, phosphorus $(\mathrm{P})$, potassium $(\mathrm{K})$, calcium $(\mathrm{Ca})$, magnesium $(\mathrm{Mg})$, total sulfur (S) content) was assessed.

\section{Macronutrient content and accumulation}

The dry plant material (roots and shoots separately) was subjected to chemical analyses according to well-known and commonly used procedures: the classic Kjeldahl procedure for the determination of total $\mathrm{N}$, the molybdenum vanadate technique for total $\mathrm{P}$, the flame-photometric method (atomic absorption spectrometry (AAS)) for K and $\mathrm{Ca}$, the colorimetric method with the use of titan yellow for $\mathrm{Mg}$, and the nephelometric Butters-Chenery method for estimating the total $\mathrm{S}$ content. The determination of $\mathrm{N}$ and $\mathrm{P}$ was performed after wet mineralization in sulfuric acid. The results concerning the macronutrient content were used to calculate the accumulation of macronutrients and their ratios $(\mathrm{K} /(\mathrm{Ca}+\mathrm{Mg}), \mathrm{Ca} / \mathrm{Mg}, \mathrm{Ca} / \mathrm{P}, \mathrm{N} / \mathrm{S}-$ ratio). The accumulation of the nutrient content was calculated by multiplying dry weight (DW) of plants by the concentration of each nutrient in the biomass (Bessa et al. 2013).

\section{Nickel determination}

Analyses of the Ni content in roots and shoots was carried out using the classic atomic AAS method, following prior dry mineralization of $5.000 \mathrm{~g}$ plant samples at $500{ }^{\circ} \mathrm{C}$, dissolved in $20 \% \mathrm{HNO}_{3}$. Ni analyses were performed by an accredited laboratory of the Regional Chemical-Agricultural Station in Lublin. In this work, data concerning the Ni accumulation have been presented. The total amount of $\mathrm{Ni}$ accumulated in under- and aboveground parts were calculated based on the concentration of this metal in the plant parts and dry matter yields (Pereira et al. 2011).

\section{Statistical analysis}

The experiment covered 12 treatments, 20 repetitions in each treatment, and 3 repetitions over time. The results of chemical analyses obtained were processed statistically by the two-way analysis of variance (ANOVA) using the STATISTICA 9 software (StatSoft, Inc. 2009). The experimental factors were the level of S nutrition of plants and the Ni content in the nutritional environment. Mean values were compared by the Tukey's post hoc test and the differences were considered significant at $P \leq 0.05$. Comparison of values in the same treatment as well as mean values among each treatment obtained from each of the three independent replicates of the experiment over the time did not show statistically proven differences. Therefore, the data presented in the tables and in the figures represent mean values obtained from nine measurements (three measurements made per each independent repetition of the experiment over the time).

\section{Results}

\section{Dry matter}

Irrespective of the $\mathrm{S}$ level in the nutrient solution, the presence of increasing Ni concentrations $(0.0004-0.08 \mathrm{mM})$ significantly elevated wheat root biomass (Fig. 1). At the same time, the lower Ni doses $(0.0004$ and $0.04 \mathrm{mM})$ did not change markedly, but the highest dose of this element used $(0.08 \mathrm{mM})$ decreased shoot biomass. However, Ni presence in the nutrient solution at the standard $\mathrm{S}$ dose $(2 \mathrm{mM})$ resulted in a significant drop in the root and shoot biomass (Fig. 1).

Under the intensive $\mathrm{S}$ nutrition with the dose $6 \mathrm{mM}$, there was a significant increase found in the root biomass of the $\mathrm{Ni}$ stressed wheat accompanied by the lack of statistically proven changes of shoot biomass at the lower and medium Ni concentration and significant decrease of under the highest $\mathrm{Ni}$ 

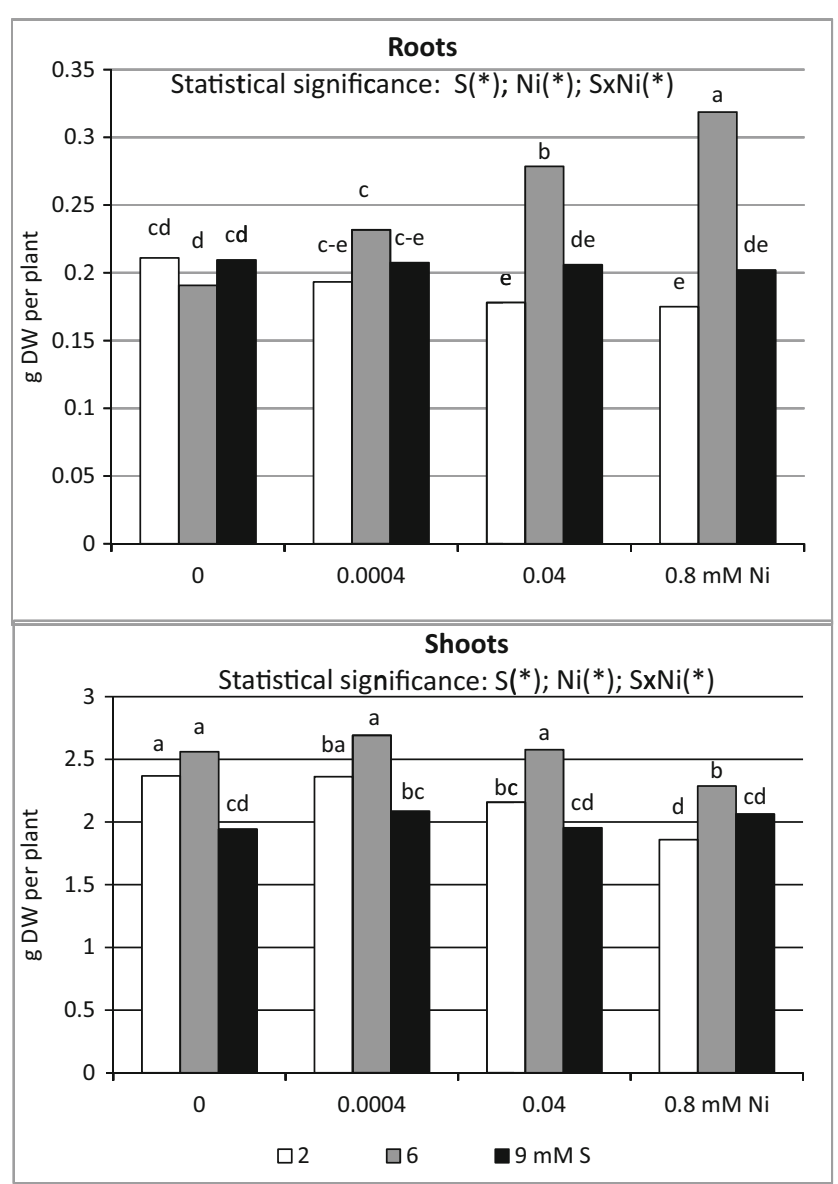

Fig. 1 Dry yield matter of spring wheat cv. Zebra grown under different sulfur (S) and/or nickel (Ni) concentrations in the nutrient solution. Results are mean of nine replications. Means marked by the same letter are not different at $P \leq 0.05$ based on the Tukey's honestly significance test. Significant effects for the main factors and for the interaction between them are indicated with asterisks

concentration used in the experiment. Simultaneously, the dose $9 \mathrm{mM} \mathrm{S}$ did not change the root and shoot productivity defined as the amount of dry matter produced by plant during the vegetation (Fig. 1).

There was a significant effect of $\mathrm{S}$ and $\mathrm{Ni}$ interaction on the productivity of under- and aboveground wheat parts (Fig. 1). It was shown that high $\mathrm{S}$ supplementation of Ni-exposed plants, as compared to standard dose $2 \mathrm{mM} \mathrm{S}$ in general significantly raised $(6 \mathrm{mM})$ or did not substantially change ( $9 \mathrm{mM} \mathrm{S}$ ) the dry weigh of roots and shoots.

\section{Macronutrient content and accumulation}

The results indicated that the Ni presence in the nutrient solution $(0.0004,0.04$, and $0.08 \mathrm{mM})$, irrespective of the $\mathrm{S}$ level, substantially reduced the $\mathrm{P}, \mathrm{K}, \mathrm{Ca}, \mathrm{Mg}$, and $\mathrm{S}$ content in wheat shoots, except for the insignificant changes in the $\mathrm{Mg}$ content at the low Ni contamination level. Simultaneously, the N content in the aboveground parts of the Ni-stressed wheat increased at the lowest, remained quite stable at the medium, and dropped at the highest Ni contamination (Table 1). In turn, in the roots, a decrease in the $\mathrm{K}$ and $\mathrm{Ca}$ content was found, together with insignificant changes in the contents of $\mathrm{N}, \mathrm{P}$, $\mathrm{Mg}$, and $\mathrm{S}$. An exception was the substantial drop in the $\mathrm{N}$ content at $0.08 \mathrm{mM} \mathrm{Ni}$ and the decrease in the $\mathrm{Mg}$ content at $0.04 \mathrm{mM} \mathrm{Ni}$ as well as the lack of statistically proven changes in the $\mathrm{K}$ content under the $0.08 \mathrm{mM} \mathrm{Ni}$ and $\mathrm{Ca}$ content under $0.04 \mathrm{mM} \mathrm{Ni}$ (Table 1). Moreover, it was shown that the increasing Ni level in the nutrient solution, irrespective of the $\mathrm{S}$ level, significantly decreased $\mathrm{P}, \mathrm{K}$, and $\mathrm{S}$ bioaccumulation, but did not markedly affect the bioaccumulation of $\mathrm{Mg}$. Only changes in $\mathrm{S}$ accumulation in wheat treated with $0.08 \mathrm{mM}$ Ni were insignificant (Table 2). Simultaneously, Ni doses 0.0004 and $0.04 \mathrm{mM}$ did not significantly affect the accumulation of $\mathrm{N}$ and $\mathrm{Ca}$, but the $\mathrm{Ni}$ concentration $0.08 \mathrm{mM}$ substantially decreased the accumulation of both these macronutrients in the wheat biomass (Table 2).

As a result of intensive $\mathrm{S}$ nutrition (6 and $9 \mathrm{mM} \mathrm{S}$ ) of the Ni-treated spring wheat $(0.0004-0.08 \mathrm{mM})$, an increase in the root $\mathrm{N}$ content together with a substantially unchanged root content of $\mathrm{P}$ was observed. Simultaneously, the shoot content of both these macronutrients increased at $6 \mathrm{mM}$ and remained quite stable at $9 \mathrm{mM} \mathrm{S}$ (Table 1). It was also shown that the high $\mathrm{S}$ level in the nutrient medium of Ni-exposed wheat markedly reduced the $\mathrm{K}$ content in the roots and raised it in the shoots, while at the same time, the root $\mathrm{Ca}$ content increased but the shoot content of this macronutrient did not change substantially. Moreover, the results obtained indicate that, depending on the $\mathrm{S}$ dose, the root $\mathrm{Mg}$ content of the $\mathrm{Ni}$ contaminated plants did not changed substantially $(6 \mathrm{mM})$ and dropped $(9 \mathrm{mM})$. Simultaneously, no significant change in the shoot $\mathrm{Mg}$ content was recorded. Furthermore, it was found that the shoot and root $\mathrm{S}$ content in the $\mathrm{Ni}$-stressed wheat intensively supplied with $\mathrm{S}$ raised significantly (Table 1).

The macronutrient accumulation in the wheat biomass under Ni treatments at different $\mathrm{S}$ levels depended on the $\mathrm{S}$ dose rather than on the Ni concentration in the nutrient solution (Table 2). Intensive $\mathrm{S}$ nutrition with the dose $6 \mathrm{mM}$ under conditions of $\mathrm{Ni}$ presence resulted in a significant increase in bioaccumulation of all macronutrients, while the S dose $9 \mathrm{mM} \mathrm{S}$ substantially increased $\mathrm{S}$ and decreased $\mathrm{N}$ and $\mathrm{K}$ accumulation but $\mathrm{P}, \mathrm{Ca}$, and $\mathrm{Mg}$ accumulation was not significantly changed (Table 2).

There was a significant effect of $\mathrm{S}$ and Ni interaction on the root and shoot content of macronutrients as well as on accumulation thereof in wheat (Tables 1 and 2). It worth to stress the increase in $\mathrm{N}$ and $\mathrm{S}$ as well as decrease in $\mathrm{K}$ and $\mathrm{Mg}$ contents recorded in roots of $\mathrm{Ni}$-exposed plants intensive fertilized with S. Simultaneously, root P content did not change significantly at 0.0004 , raised at 0.04 and dropped at the concentration $0.08 \mathrm{mM} \mathrm{Ni}$. In turn, in shoots of Ni-exposed wheat intensive supplied with $\mathrm{S}$, the significant increase in $\mathrm{P}$ and $\mathrm{Ca}$ content accompanied by the slight changes in $\mathrm{N}$ and $\mathrm{Mg}$ content were recorded. The exceptions were insignificant changes 


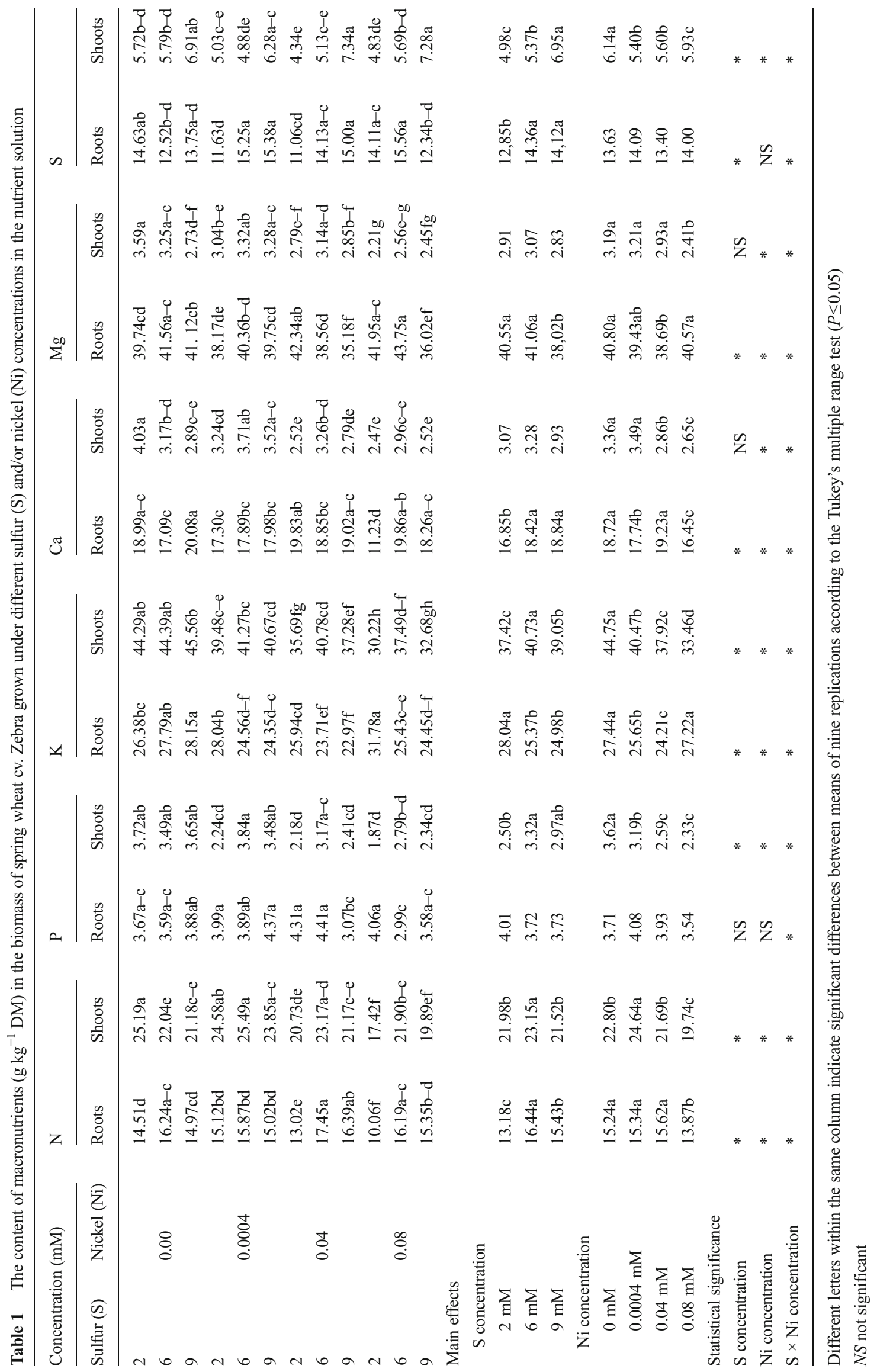


Table 2 Macronutrients accumulation (mg per plant) in the biomass of spring wheat cv. Zebra grown under different sulfur (S) and/or nickel (Ni) concentrations in the nutrient solution

\begin{tabular}{|c|c|c|c|c|c|c|c|}
\hline \multicolumn{2}{|c|}{ Concentration (mM) } & \multirow[b]{2}{*}{$\mathrm{N}$} & \multirow[b]{2}{*}{$\mathrm{P}$} & \multirow[b]{2}{*}{$\mathrm{K}$} & \multirow[b]{2}{*}{$\mathrm{Ca}$} & \multirow[b]{2}{*}{$\mathrm{Mg}$} & \multirow[b]{2}{*}{ S } \\
\hline Sulfur (S) & Nickel (Ni) & & & & & & \\
\hline 2 & & $62.80 \mathrm{~b}$ & $9.58 \mathrm{ab}$ & $110.44 a b$ & $13.55 \mathrm{ab}$ & $16.88 \mathrm{~b}-\mathrm{d}$ & $16.63 \mathrm{a}$ \\
\hline 6 & 0.00 & $59.54 b c$ & $9.62 \mathrm{ab}$ & $116.42 \mathrm{a}$ & $11.37 \mathrm{bc}$ & $16.25 \mathrm{c}-\mathrm{e}$ & $17.21 \mathrm{a}$ \\
\hline 9 & & $44.26 \mathrm{~d}$ & $7.90 \mathrm{~b}$ & $94.37 \mathrm{c}$ & $9.82 \mathrm{c}$ & $13.91 \mathrm{~d}-\mathrm{g}$ & $16.30 \mathrm{ab}$ \\
\hline 2 & & $60.98 b$ & $6.06 \mathrm{de}$ & $98.68 \mathrm{bc}$ & $11.00 \mathrm{bc}$ & $14.56 \mathrm{~d}-\mathrm{f}$ & $14.13 b$ \\
\hline 6 & 0.0004 & $73.39 \mathrm{a}$ & $11.51 \mathrm{a}$ & $118.48 \mathrm{a}$ & $15.38 \mathrm{a}$ & $21.11 \mathrm{a}$ & $17.73 \mathrm{a}$ \\
\hline 9 & & $42.15 d$ & $6.60 \mathrm{~d}$ & $71.62 \mathrm{ef}$ & $9.49 \mathrm{c}$ & $13.62 \mathrm{e}-\mathrm{g}$ & $13.47 \mathrm{c}$ \\
\hline 2 & & $47.05 \mathrm{~d}$ & $5.47 \mathrm{de}$ & $81.63 \mathrm{de}$ & $8.96 \mathrm{c}$ & $13.55 \mathrm{e}-\mathrm{g}$ & $11.33 \mathrm{c}$ \\
\hline 6 & 0.04 & $64.57 b$ & $9.40 \mathrm{a}-\mathrm{c}$ & $111.69 \mathrm{a}$ & $13.65 \mathrm{ab}$ & $18.83 \mathrm{a}-\mathrm{c}$ & $17.15 \mathrm{a}$ \\
\hline 9 & & $44.73 d$ & $5.34 \mathrm{de}$ & $77.55 \mathrm{e}$ & $9.36 \mathrm{c}$ & $12.81 \mathrm{fg}$ & $17.43 \mathrm{a}$ \\
\hline 2 & & $34.15 \mathrm{e}$ & $4.19 \mathrm{e}$ & $61.76 f$ & $6.56 \mathrm{~d}$ & $11.45 \mathrm{~g}$ & $11.45 \mathrm{c}$ \\
\hline 6 & 0.08 & $55.26 \mathrm{c}$ & $7.33 \mathrm{~cd}$ & $93.86 \mathrm{~cd}$ & $13.10 \mathrm{a}$ & $19.79 \mathrm{ab}$ & $17.97 \mathrm{a}$ \\
\hline 9 & & $44.14 d$ & $5.44 \mathrm{de}$ & $72.37 \mathrm{ef}$ & $8.89 \mathrm{~cd}$ & $12.33 \mathrm{fg}$ & $17.51 \mathrm{a}$ \\
\hline \multicolumn{8}{|c|}{ Main effects } \\
\hline \multicolumn{8}{|c|}{$\mathrm{S}$ concentration } \\
\hline $2 \mathrm{mM}$ & & $51.22 \mathrm{~b}$ & $6.32 b$ & $88.13 b$ & $10.02 \mathrm{~b}$ & $14.11 b$ & $13.39 \mathrm{c}$ \\
\hline $6 \mathrm{mM}$ & & $63.19 \mathrm{a}$ & $9.46 \mathrm{a}$ & $110.12 \mathrm{a}$ & $13.37 \mathrm{a}$ & $18.99 \mathrm{a}$ & $17.52 \mathrm{a}$ \\
\hline $9 \mathrm{mM}$ & & $43.83 \mathrm{c}$ & $6.35 \mathrm{~b}$ & $78.99 \mathrm{c}$ & $9.39 \mathrm{~b}$ & $13.16 \mathrm{~b}$ & $16.18 \mathrm{~b}$ \\
\hline \multicolumn{8}{|c|}{ Ni concentration } \\
\hline $0 \mathrm{mM}$ & & $55.51 \mathrm{ab}$ & $9.04 \mathrm{a}$ & $107.09 \mathrm{a}$ & $11.58 \mathrm{a}$ & 15.68 & $16.72 \mathrm{a}$ \\
\hline 0.000 & $\mathrm{nM}$ & $58.84 \mathrm{a}$ & $8.06 \mathrm{a}$ & $96.26 b$ & $11.96 \mathrm{a}$ & 16.43 & $15.11 b$ \\
\hline $0.04 \mathrm{n}$ & & $52.12 \mathrm{~b}$ & $6.73 b$ & $90.29 b$ & $10.66 \mathrm{ab}$ & 15.06 & $15.30 \mathrm{~b}$ \\
\hline $0.08 \mathrm{n}$ & & $44.52 \mathrm{~d}$ & $5.69 \mathrm{~b}$ & $76.00 \mathrm{c}$ & $9.51 \mathrm{~b}$ & 14.52 & $15.64 \mathrm{ab}$ \\
\hline \multicolumn{8}{|c|}{ Statistical significance } \\
\hline S concentra & & $*$ & $*$ & $*$ & $*$ & $*$ & $*$ \\
\hline Ni concent & & * & * & $*$ & $*$ & NS & $*$ \\
\hline $\mathrm{S} \times \mathrm{Ni}$ con & tration & $*$ & $*$ & $*$ & $*$ & $*$ & $*$ \\
\hline
\end{tabular}

Different letters within the same column indicate significant differences between means of nine replications according to the Tukey's multiple range test $(P \leq 0.05)$

NS not significant in $\mathrm{P}$ and $\mathrm{Ca}$ content recorded at the highest $\mathrm{Ni}$ concentrations used in the experiment. It was shown that high $\mathrm{S}$ supplementation of Ni-exposed plants, in general, significantly raised at $6 \mathrm{mM}$ and did not substantially change at the $\mathrm{S}$ level $9 \mathrm{mM}$ the $\mathrm{K}$ content in shoots, while shoot $\mathrm{S}$ content remained unchanged and elevated, respectively. Furthermore, it was shown that the intensive $\mathrm{S}$ nutrition of Ni-exposed plants, in general, significantly raised $(6 \mathrm{mM})$ or did not change markedly ( $9 \mathrm{mM} \mathrm{S}$ ) the bioaccumulation of $\mathrm{N}, \mathrm{P}, \mathrm{K}, \mathrm{Ca}$, and $\mathrm{Mg}$ excluding increase in $\mathrm{N}$ bioaccumulation shown for the treatment $9 \mathrm{mM} \mathrm{S} / 0.08 \mathrm{mM} \mathrm{Ni}$. All these changes were accompanied by the rise in $\mathrm{S}$ bioaccumulation.

\section{Macronutrient ratios}

Irrespective of the $\mathrm{S}$ level in the nutrient solution, the increasing $\mathrm{Ni}$ contamination did not affect the N/S ratio in wheat roots and shoots (Table 3$)$. Simultaneously, the shoot $\mathrm{K}(\mathrm{Ca}+$
$\mathrm{Mg}$ ) ratio was substantially lower, while the value of this ratio in roots at the 0.0004 and $0.08 \mathrm{mM} \mathrm{Ni}$ ratio was quite stable, but significantly dropped at $0.04 \mathrm{mM} \mathrm{Ni}$. The increasing Ni level in the nutrient solution did not cause significant changes in the shoot $\mathrm{Ca} / \mathrm{Mg}$ ratio, but the value of this ratio in roots was reduced at 0.0004 and $0.08 \mathrm{mM} \mathrm{Ni}$ and was elevated at $0.04 \mathrm{mM} \mathrm{Ni}$. Under conditions of the low Ni concentration $(0.0004 \mathrm{mM})$, intensive $\mathrm{S}$ fertilization resulted in a decrease in root $\mathrm{Ca} / \mathrm{P}$, but at the high $\mathrm{Ni}$ contamination $(0.04$ and $0.08 \mathrm{mM}$ ) the value of this ratio was unaffected. Simultaneously, in the Ni-stressed plants, irrespective of the $\mathrm{S}$ level in the nutrient solution, the shoot value of this ratio was substantially higher (Table 3).

The results obtained indicate that the increased $\mathrm{S}$ level (6 and $9 \mathrm{mM}$ ) in the Ni-contaminated nutrient solution, irrespective of the Ni concentration, resulted in a decrease in the root $\mathrm{K} /(\mathrm{Ca}+\mathrm{Mg})$ ratio, but in shoots, the values of this ratio were not significantly different (Table 3 ). Simultaneously, a 
Table 3 Ratios of macronutrients in the biomass of spring wheat cv. Zebra grown under different sulfur (S) and/or nickel (Ni) concentrations in the nutrient solution

\begin{tabular}{|c|c|c|c|c|c|c|c|c|c|}
\hline \multicolumn{2}{|c|}{ Concentration (mM) } & \multicolumn{2}{|c|}{$\begin{array}{l}\mathrm{K} /(\mathrm{Ca}+\mathrm{Mg}) \\
\text { mole }\end{array}$} & \multicolumn{2}{|l|}{$\begin{array}{l}\mathrm{Ca} / \mathrm{Mg} \\
\text { mass }\end{array}$} & \multicolumn{2}{|l|}{$\begin{array}{l}\mathrm{Ca} / \mathrm{P} \\
\text { mass }\end{array}$} & \multicolumn{2}{|l|}{$\begin{array}{l}\mathrm{N} / \mathrm{S} \\
\text { mass }\end{array}$} \\
\hline Sulfur (S) & Nickel (Ni) & Roots & Shoots & Roots & Shoots & Roots & Shoots & Roots & Shoots \\
\hline 2 & & $0.53 \mathrm{~d}$ & $2.28 \mathrm{~cd}$ & $0.48 \mathrm{a}-\mathrm{c}$ & $1.12 \mathrm{ab}$ & $5.17 \mathrm{~b}$ & $1.08 \mathrm{c}$ & $0.99 \mathrm{e}$ & $4.40 \mathrm{ab}$ \\
\hline 6 & 0.00 & $0.60 \mathrm{bc}$ & $2.67 \mathrm{~b}$ & $0.41 \mathrm{de}$ & $0.98 \mathrm{~d}$ & $4.76 \mathrm{~cd}$ & $0.91 \mathrm{ef}$ & $1.30 \mathrm{a}$ & $3.81 \mathrm{~cd}$ \\
\hline 9 & & $0.54 \mathrm{~d}$ & $3.16 \mathrm{a}$ & $0.49 \mathrm{a}-\mathrm{c}$ & $1.06 \mathrm{bc}$ & $5.18 b$ & $0.79 \mathrm{f}$ & $1.09 \mathrm{~cd}$ & $3.07 \mathrm{e}$ \\
\hline 2 & & $0.61 b$ & $2.34 \mathrm{~b}-\mathrm{e}$ & $0.38 \mathrm{e}$ & $1.07 \mathrm{bc}$ & $4.34 \mathrm{ef}$ & $1.45 \mathrm{a}$ & $1.30 \mathrm{a}$ & $4.89 \mathrm{a}$ \\
\hline 6 & 0.0004 & $0.52 \mathrm{~d}$ & $2.13 \mathrm{e}$ & $0.44 \mathrm{~cd}$ & $1.12 \mathrm{ab}$ & 4.60de & $0.97 \mathrm{de}$ & $1.04 \mathrm{de}$ & $3.25 \mathrm{~d}-\mathrm{f}$ \\
\hline 9 & & $0.52 \mathrm{~d}$ & $2.19 \mathrm{de}$ & $0.45 \mathrm{~b}-\mathrm{d}$ & $1.07 \mathrm{ab}$ & $4.11 \mathrm{f}$ & $1.01 \mathrm{c}-\mathrm{e}$ & $0.98 \mathrm{e}$ & $3.80 \mathrm{~cd}$ \\
\hline 2 & & $0.51 \mathrm{~d}$ & $2.56 \mathrm{~b}-\mathrm{d}$ & $0.47 \mathrm{~b}-\mathrm{d}$ & $0.90 \mathrm{e}$ & $4.60 \mathrm{de}$ & $1.16 \mathrm{bc}$ & $1.18 \mathrm{bc}$ & $4.78 \mathrm{a}$ \\
\hline 6 & 0.04 & $0.53 \mathrm{~d}$ & $2.39 \mathrm{~b}-\mathrm{e}$ & $0.49 \mathrm{a}-\mathrm{c}$ & $1.04 \mathrm{~cd}$ & $4.27 \mathrm{ef}$ & $1.03 \mathrm{c}-\mathrm{e}$ & $1.24 \mathrm{ab}$ & $4.52 \mathrm{a}$ \\
\hline 9 & & $0.51 \mathrm{~d}$ & $2.50 \mathrm{~b}-\mathrm{e}$ & $0.54 \mathrm{a}$ & $0.98 \mathrm{~d}$ & $6.20 \mathrm{~b}$ & $1.16 b c$ & $1.09 \mathrm{~cd}$ & $2.88 \mathrm{ef}$ \\
\hline 2 & & $0.70 \mathrm{a}$ & $2.43 \mathrm{~b}-\mathrm{e}$ & $0.27 \mathrm{f}$ & $1.12 \mathrm{ab}$ & $2.77 \mathrm{~g}$ & $1.32 \mathrm{ab}$ & $0.71 \mathrm{f}$ & $3.61 \mathrm{c}-\mathrm{e}$ \\
\hline 6 & 0.08 & $0.51 \mathrm{~d}$ & $2.60 \mathrm{bc}$ & $0.45 b-d$ & $1.16 \mathrm{a}$ & $6.64 \mathrm{a}$ & $1.06 \mathrm{c}-\mathrm{e}$ & $1.04 \mathrm{~d}$ & $3.85 \mathrm{bc}$ \\
\hline 9 & & $0.55 \mathrm{~cd}$ & $2.49 \mathrm{be}$ & $0.51 \mathrm{ab}$ & $1.03 \mathrm{~cd}$ & $5.10 \mathrm{bc}$ & $1.08 \mathrm{~cd}$ & $1.24 \mathrm{ab}$ & $2.73 \mathrm{f}$ \\
\hline \multicolumn{10}{|c|}{ Main effects } \\
\hline \multicolumn{10}{|c|}{ S concentration } \\
\hline $2 \mathrm{mM}$ & & $0.59 \mathrm{a}$ & 2.40 & $0.40 \mathrm{~b}$ & 1.05 & $4.22 \mathrm{~b}$ & $1.25 \mathrm{a}$ & $1.05 \mathrm{c}$ & $4.42 \mathrm{a}$ \\
\hline $6 \mathrm{mM}$ & & $0.54 b$ & 2.45 & $0.45 \mathrm{a}$ & 1.08 & $5.07 \mathrm{a}$ & $0.99 b$ & $1.16 \mathrm{a}$ & $3.86 b$ \\
\hline $9 \mathrm{mM}$ & & $0.53 b$ & 2.59 & $0.49 \mathrm{a}$ & 1.04 & $5.15 \mathrm{a}$ & $1.01 \mathrm{~b}$ & $1.10 \mathrm{~b}$ & $3.12 \mathrm{c}$ \\
\hline $0 \mathrm{mM}$ & & $0.56 \mathrm{ab}$ & $2.70 \mathrm{a}$ & $0.46 \mathrm{~b}$ & 1.05 & $5.04 \mathrm{a}$ & $0.93 b$ & 1.13 & 3.76 \\
\hline \multicolumn{10}{|c|}{$\mathrm{Ni}$ concentration } \\
\hline 0.000 & & $0.55 \mathrm{bc}$ & $2.22 \mathrm{c}$ & $0.42 \mathrm{c}$ & 1.09 & $4.35 b$ & $1.14 \mathrm{a}$ & 1.11 & 3.98 \\
\hline $0.04 \mathrm{r}$ & & $0.52 \mathrm{c}$ & $2.48 \mathrm{~b}$ & $0.50 \mathrm{a}$ & 0.97 & $5.02 \mathrm{a}$ & $1.12 \mathrm{a}$ & 1.17 & 4.06 \\
\hline $0.08 \mathrm{r}$ & & $0.59 \mathrm{a}$ & $2.51 \mathrm{~b}$ & $0.41 \mathrm{c}$ & 1.10 & $4.84 \mathrm{a}$ & $1.15 \mathrm{a}$ & 1.00 & 3.40 \\
\hline \multicolumn{10}{|c|}{ Statistical significance } \\
\hline S concentre & & $*$ & NS & $*$ & NS & $*$ & $*$ & $*$ & $*$ \\
\hline Ni concent & & $*$ & $*$ & $*$ & NS & $*$ & * & NS & NS \\
\hline $\mathrm{S} \times \mathrm{Ni}$ con & ation & $*$ & $*$ & $*$ & $*$ & $*$ & $*$ & $*$ & $*$ \\
\hline
\end{tabular}

Different letters within the same column indicate significant differences between means of nine replications according to the Tukey's multiple range test $(P \leq 0.05)$

NS not significant

significant increase in the root $\mathrm{Ca} / \mathrm{Mg}, \mathrm{Ca} / \mathrm{P}$, and $\mathrm{N} / \mathrm{S}$ ratios was noticed, while in shoots, the value of the $\mathrm{Ca} / \mathrm{Mg}$ ratio remained quite stable, but the $\mathrm{Ca} / \mathrm{P}$ and $\mathrm{N} / \mathrm{S}$ ratio was substantially lower (Table 3 ).

There was a significant effect of $\mathrm{S}$ and $\mathrm{Ni}$ interaction on the value of $\mathrm{K} /(\mathrm{Ca}+\mathrm{Mg}), \mathrm{Ca} / \mathrm{Mg}, \mathrm{Ca} / \mathrm{P}$, and $\mathrm{N} / \mathrm{S}$ in shoots and roots. The elevated $\mathrm{S}$ level in $\mathrm{Ni}$ containing nutrient solution significantly dropped the root $\mathrm{K} /(\mathrm{Ca}+$ $\mathrm{Mg}$ ) ratio and did not change the value of this ratio in shoots, except for insignificant changes in root shown for the medium $\mathrm{Ni}$ level used in the experiment $(0.04 \mathrm{mM})$. At the same time, $\mathrm{Ca} / \mathrm{Mg}$ ratio in roots of $\mathrm{Ni}$-stressed wheat was increased under conditions of intensive S fertilization, while in shoots, was slightly changed at lowest (0.0004), increased at medium (0.04) and decreased at the highest $(0.08 \mathrm{mM})$ used in the experiment $\mathrm{Ni}$ concentration. In turn, the root value of $\mathrm{Ca} / \mathrm{P}$ ratio of objects intensive supplied with $\mathrm{S}$ was not markedly affected at $0.0004 \mathrm{mM}$ and raised at the higher $\mathrm{Ni}$ concentrations in nutrient solution $(0.04$ and $0.08 \mathrm{mM})$, while in shoots, the value of this ration dropped at the lowest and at the highest but did not change at the medium Ni concentration used in the experiment. Furthermore it was shown that high $\mathrm{S}$ supplementation of $\mathrm{Ni}$-exposed plants, in general, significantly raised, and the $\mathrm{S}$ dose $6 \mathrm{mM}$ and did not substantially change at S level $9 \mathrm{mM}$ the value of shoot N/S ratio, while the root value of this ratio substantially decreased at 0.0004 , remained unchanged at 0.04 and increased at the concentration $0.08 \mathrm{mM} \mathrm{Ni}$. 


\section{Nickel accumulation}

The results obtained indicate that, irrespective of the $\mathrm{S}$ level in the nutrient solution, $\mathrm{Ni}$ accumulation in the spring wheat biomass rose together with the increasing concentration of this element in the nutrient medium and that the increase in Ni accumulation was much more pronounced in shoots than in roots (Fig. 2). Depending on the Ni level in the nutrient solution, wheat accumulated 7-10 (0.0004 mM), 16-28 (0.04 mM), and 13-14 times $(0.08 \mathrm{mM} \mathrm{Ni})$ larger amounts of $\mathrm{Ni}$ in shoots than in roots. Irrespective of the $\mathrm{Ni}$ level in the nutrient solution, the intensive $\mathrm{S}$ nutrition (6 and $9 \mathrm{mM}$ ) significantly increased $\mathrm{Ni}$ accumulation in roots. Simultaneously, shoot Ni accumulation remained quite stable at $6 \mathrm{mM}$, but dropped markedly at $9 \mathrm{mM} \mathrm{S}$. There was a significant effect of $\mathrm{S}$ and $\mathrm{Ni}$ on the $\mathrm{Ni}$ accumulation in the under- and aboveground parts of wheat (Fig. 2). It is worthy to stress

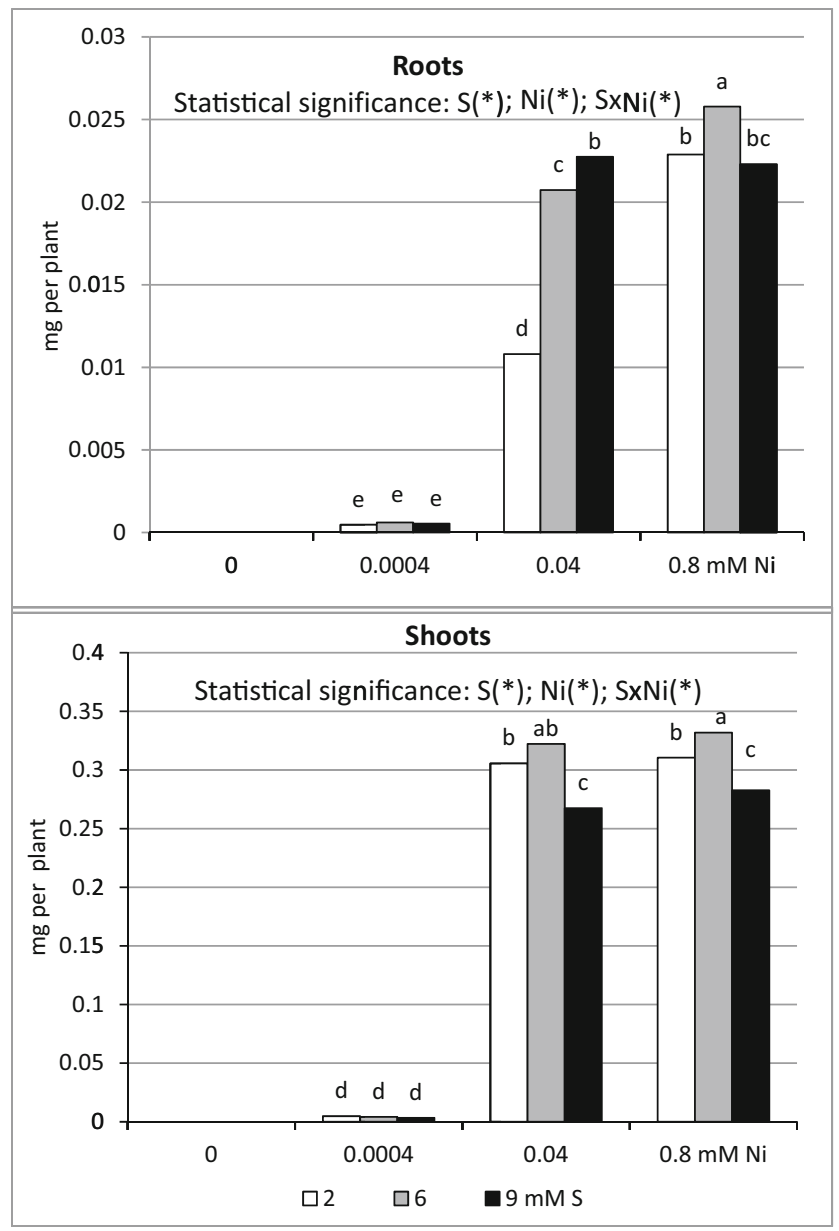

Fig. 2 Nickel accumulation in the biomass of spring wheat cv. Zebra grown under different sulfur (S) and/or nickel (Ni) concentrations in the nutrient solution. Note: In control plants $(\mathrm{Ni}=0 \mathrm{mM})$ in basic $(\mathrm{S}=2)$ and high $\mathrm{S}(\mathrm{S}=6$ or $9 \mathrm{mM})$ treated plants only trace amounts of nickel were identified and, hence, accumulations were zero. See Fig. 1 for further explanation. statistically proven increase in the $\mathrm{Ni}$ accumulation in the root biomass of intensive fertilized with $\mathrm{S}$ plants exposed to medium and the highest $\mathrm{Ni}$ concentrations used in the experiment, excluding the treatment $9 \mathrm{mM} \mathrm{S} / 0.08 \mathrm{mM} \mathrm{Ni}$ where $\mathrm{Ni}$ accumulation remained quite stable. In turn, in the shoot biomass, the decrease in $\mathrm{Ni}$ accumulation shown in high Ni stressed $(0.04$ and $0.08 \mathrm{mM})$ objects supplemented with the $\mathrm{S}$ dose $6 \mathrm{mM}$ should be mentioned.

\section{Discussion}

The Ni concentration used in the present study ranged between 0.0004 and $0.08 \mathrm{mM}$. The lowest concentration of this micronutrient in the nutrient solution is regarded as the highest permissible level in ground water. Moreover, the dose $0.0004 \mathrm{mM} \mathrm{Ni}$ exceeds about eight times the background concentration of this element in ground water and 1.3 times the global average value. The level of $\mathrm{Ni}$ from water in industrial regions tends to be from $6 \times 10^{-4}$ to $6 \times 10^{-2} \mathrm{mM}$. For protection of aquatic organisms, Soil Quality Assessment Guideline (SQAG) established a value of threshold effect levels (TEL) at $3 \times 10^{-5} \mathrm{mM}$ and probable effect levels (PEL) at $75 \times 110^{-6} \mathrm{mM}$ (Lander 2003; Kabata-Pendias and Mukherjee 2007). The second experimental factor was various $\mathrm{S}_{-} \mathrm{SO}_{4}$ concentrations in the nutrient solution. The standard $\mathrm{S}_{-} \mathrm{SO}_{4}$ level used in the presented studies $(2 \mathrm{mM} \mathrm{S})$ is considered moderate. It is assumed that the $\mathrm{S}_{-} \mathrm{SO}_{4}$ concentration in the natural environment, i.e., unpolluted with heavy metals, ranges from 0.16 to 7 , in arid regions from 3 to $16 \mathrm{mM}$, while the $\mathrm{SO}_{4}{ }^{2-}$ concentration in soil solutions with residues of sulfide ore mine oscillates between 13 and $110 \mathrm{mM}$ (Ernst et al. 2008).

\section{Macronutrient content and accumulation}

Disturbances in essential element balance and ionic homeostasis is considered a crucial mechanism of $\mathrm{Ni}$ toxicity in plants. The data concerning the $\mathrm{Ni}$ impact on plant mineral nutrition are inconclusive. Mineral nutrient content in particular organs of Ni-stressed plants may decrease, remain quite stable, or increase (Rubio et al. 1994; Sreekanth et al. 2013). The decrease in the content of all examined macronutrients found in the presented studies for the Ni-stressed wheat may be explained, inter alia, by low-energy status as a result of respiration disturbances, which decreases active uptake and nutrient transport. Due to the comparable ionic radii of $\mathrm{Ni}^{2+}$ and other cations of essential nutrients, they may compete for common biding sites. Ni may also turn off nutrients (especially $\mathrm{Ca}, \mathrm{Mg}, \mathrm{Fe}, \mathrm{Zn}, \mathrm{Cu}$ ) from their physiological function. Replacement of the essential metal of metalloproteins, binding to catalytic residues of non-metalloenzymes, binding outside the catalytic site of an enzyme to inhibit allosterically, and 
causing oxidative stress are mechanisms of $\mathrm{Ni}$ toxicity often described in the literature (Chen et al. 2009; Gospodarek and Nadgórska-Socha 2010; da Silva et al. 2012a, b; Osu and Isaac 2014). Ni affects the composition and permeability of cell membrane by changing sterol and phospholipid levels as well as structural conformation and ATPase activity. Proton pump H-ATPase is involved in active uptake and transport of essential elements, which depends on the availability of metabolic energy utilized for cell membrane polarization. The indirect effect of $\mathrm{Ni}$ on enzyme activity arises from ioninduced imbalances due to competitive inhibition of absorption and transport of macro- and micronutrients, while the direct one involves strong $\mathrm{Ni}$ affinity for functional sulfhydryl groups (-SH) of enzymes and, in consequence, alteration of protein conformation thereby causing inactivation thereof and metabolic disorders (Janicka-Russak et al. 2008; Sanz et al. 2009; Sharma and Dhiman 2013; Sreekanth et al. 2013). Thus, $\mathrm{Ni}$ exposure alters sulfhydryl homeostasis. The primary route for $\mathrm{Ni}$ toxicity is depletion of GSH and bonding to the $-\mathrm{SH}$ groups of proteins. Ni tolerance and the detoxification process is associated with $\mathrm{S}$ metabolism, especially with high levels of OAS (O-acetyl-L-serine), Cys, and GSH in the biomass due to high activity of Ser acetyltransferase (SAR). Ni, which is a borderline metal, is able to bind with many types of chelating agents including S-donor ligands, i.e., containing highly reactive $\mathrm{S}$ functional groups which determine the durability of complexation (Bhatia et al. 2005; Seregin and Kozhevnikova 2006; Hossain et al. 2012; Viehweger 2014). Our findings revealed increased GSH content in the Nistressed wheat, elevated at $6 \mathrm{mM} \mathrm{S}$, while the content of this tripeptide dropped at $9 \mathrm{mM} \mathrm{S}$ in the nutrient solution, which may suggest that the latter level was too high for this species (data in press). Also, application of the lower S dose used in the experiment $(6 \mathrm{mM})$, irrespective of $\mathrm{Ni}$ contamination, gave much more beneficial effects on the nutrient composition in the wheat biomass compared to $9 \mathrm{mM}$. Admittedly, both $\mathrm{S}$ doses increased the $\mathrm{N}$ and $\mathrm{S}$ content in root and shoot biomass, and raised the $\mathrm{Ca}$ content in roots. In turn, the elevated $\mathrm{P}$ content was found only in the presence of $6 \mathrm{mM} \mathrm{S}$. Moreover, the level $9 \mathrm{mM} \mathrm{S}$ significantly reduced the $\mathrm{Mg}$ content in roots. Simultaneously, both S doses decreased the $\mathrm{K}$ content in roots and increased it in shoots, whereas the changes in the content of this macronutrient in under- and aboveground parts were comparable. The data obtained confirmed that excess of $\mathrm{S}$ in the nutrient environment usually results in uptake of $\mathrm{N}$ in excessive amounts (de Kok et al. 2011). These processes can also induce ion imbalance in plants and disturbance of the buffer capacity of the cell sap (Fageira 2008). In all experimental treatments, the recorded leaf $\mathrm{N}, \mathrm{K}$, and $\mathrm{S}$ content exceeded the sufficient range of these elements, which is for $\mathrm{N}, \mathrm{K}$, and $\mathrm{S}$ are 2.5 to $3.5,16$ to 30 , and 2 to $5 \mathrm{~g} \mathrm{~kg}^{-1} \mathrm{DW}$, respectively (Akhter 2012). Only the $\mathrm{S}$ content under conditions of $\mathrm{Ni}$ treatment $(0.02$ and
$0.04 \mathrm{mM})$ at the basic $\mathrm{S}$ level $(2 \mathrm{mM})$ lay within the upper limit of the optimal value. All the values of $\mathrm{Mg}, \mathrm{P}$, and $\mathrm{Ca}$ contents obtained in wheat aboveground parts oscillated within the optimal range, i.e., $1.3-4.0 \mathrm{~g} \mathrm{~kg}^{-1} \mathrm{DW}$ for $\mathrm{Mg}$ and 2 to $5 \mathrm{~g} \mathrm{~kg}^{-1}$ DW for Ca and P (Akhter 2012).

The decrease in productivity and the reduced content of $\mathrm{N}$, $\mathrm{P}, \mathrm{K}, \mathrm{Ca}$, and $\mathrm{S}$, shown in the presence of high $\mathrm{Ni}$ doses $(0.04$ and $0.8 \mathrm{mM})$ at the standard $\mathrm{S}$ level $(2 \mathrm{mM})$ resulted in unfavorable changes in accumulation thereof. Except for $\mathrm{Mg}$, the reduced accumulation of the analyzed macronutrients in the total biomass of the Ni-stressed wheat supplemented with the basic $\mathrm{S}$ dose resulted, to a greater extent, from the decrease in their content rather than the drop in productivity. In turn, $\mathrm{Mg}$ accumulation in the Ni-stressed wheat remained unchanged due to a comparably slight drop in the biomass and $\mathrm{Mg}$ content.

The positive effect of sulfur fertilization on macronutrient accumulation was shown at $6 \mathrm{mM} \mathrm{S}$. Such a phenomenon was not evident at the highest additional $\mathrm{S}$ level, i.e., $9 \mathrm{mM}$. The increased accumulation of the macronutrients $(\mathrm{N}, \mathrm{P}, \mathrm{K}, \mathrm{Ca}$, and $\mathrm{Mg}$ ) in the total biomass shown in the presence of $\mathrm{Ni}$ in the nutrient solution containing $6 \mathrm{mM} \mathrm{S}$ resulted from an increase in plant productivity rather than changes (mainly rise) in their content. $\mathrm{N}$ and $\mathrm{K}$ accumulation in the Ni-treated wheat fertilized with the highest experimental $\mathrm{S}$ dose $(9 \mathrm{mM})$ was significantly reduced due to the greater drop in productivity than the rise in their content. At the same time, $S$ accumulation rose mainly due to the marked increase in the $\mathrm{S}$ content. The unchanged $\mathrm{P}, \mathrm{Mg}$, and $\mathrm{Ca}$ accumulation in $\mathrm{Ni}$-stressed plants at $9 \mathrm{mM} \mathrm{S}$ was caused by comparable changes in the content of this element and productivity.

\section{Macronutrient ratios}

The quite stable value of the wheat root $\mathrm{K} /(\mathrm{Ca}+\mathrm{Mg})$ ratio found in the presence of 0.0004 and $0.08 \mathrm{mM} \mathrm{Ni}$ resulted from the similar decreases in the $\mathrm{K}$ and $\mathrm{Ca}$ content as well as the slight changes in the $\mathrm{Mg}$ content. At the same time, under the $\mathrm{Ni}$ concentration $0.04 \mathrm{mM}$, the root value of this ratio was lowered as a result of the greater decrease in the $\mathrm{K}$ than $\mathrm{Mg}$ content together with the slightly changed $\mathrm{Ca}$ content. At the same time, the shoot $\mathrm{K} /(\mathrm{Ca}+\mathrm{Mg})$ ratio in the Ni-stressed wheat plants was markedly lowered due to the greater decrease in the $\mathrm{K}$ than $\mathrm{Ca}$ content and the slightly changed $\mathrm{Mg}$ content. The changes in the root $\mathrm{Ca} / \mathrm{Mg}$ ratio recorded in the $\mathrm{Ni}$-stressed wheat, i.e., the drop at the 0.0004 and $0.08 \mathrm{mM} \mathrm{Ni}$ concentration as well as the rise at the $0.04 \mathrm{mM}$ Ni dose resulted mainly from the changes in the $\mathrm{Ca}$ content, while the $\mathrm{Mg}$ content remained quite stable. At the same time, the slightly changed shoot $\mathrm{Ca} / \mathrm{Mg}$ ratio was a consequence of the similar decrease in the $\mathrm{Ca}$ and $\mathrm{Mg}$ content. The quite stable root $\mathrm{Ca} / \mathrm{P}$ ratio shown in the treatments contaminated with nickel, irrespective of the $\mathrm{S}$ level in the nutrient solution, 
was due to the comparable rise (at 0.0004 and $0.04 \mathrm{mM} \mathrm{Ni}$ ) and drop (at $0.08 \mathrm{mM} \mathrm{Ni}$ ) in the $\mathrm{Ca}$ and $\mathrm{P}$ content. In turn, the elevated value of this ratio in shoots resulted from the greater decrease in the $\mathrm{P}$ than $\mathrm{Ca}$ content. The quite stable value of the $\operatorname{root} \mathrm{N} / \mathrm{S}$ ratio found under the Ni treatment, irrespective of the $\mathrm{S}$ dose, was due to the unchanged $\mathrm{N}$ and $\mathrm{S}$ content. Only the drop in the $\mathrm{N}$ content recorded under the highest Ni contamination used in the experiment $(0.08 \mathrm{mM})$ was significant. Also, the shoot N/S ratio remained unchanged. Depending on the $\mathrm{Ni}$ treatment, this was a consequence of the similar rise in $\mathrm{S}$ and the drop in the $\mathrm{N}$ content (at $0.0004 \mathrm{mM} \mathrm{Ni}$ ) as well as the comparable drop in the content of both these macronutrients (at 0.04 and $0.08 \mathrm{mM} \mathrm{Ni}$ ).

Our results revealed that in wheat fertilized with high $\mathrm{S}$ doses (6 or $9 \mathrm{mM})$, irrespective of the Ni treatment, the value of the root $\mathrm{K} /(\mathrm{Ca}+\mathrm{Mg})$ ratio significantly dropped as a result of the decrease in the $\mathrm{K}$ content and the increased $\mathrm{Ca}$ content in spite of the slightly changed (at $6 \mathrm{mM} \mathrm{S}$ ) and reduced (at $9 \mathrm{mM} \mathrm{S}) \mathrm{Mg}$ content. The values of the shoot $\mathrm{K} /(\mathrm{Ca}+\mathrm{Mg})$ obtained in the Ni-exposed wheat supplied with high $\mathrm{S}$ doses fall within the range of 2.13-2.60 and slightly exceeded the optimum range, which is $1.6-2.1: 1$, probably due to the fact that in order to maintain the ion balance, the cationic demand increases, and among the available $\mathrm{K}, \mathrm{Ca}$, and $\mathrm{Mg}$ ions in the nutrient medium, the $\mathrm{K}$ ion is much more rapidly taken up (Morgan and Connolly 2013). The shoot value in the Nistressed plants supplemented with additional $\mathrm{S}$ did not change markedly due to the slightly changed content of $\mathrm{Mg}$ at both $\mathrm{S}$ doses as well as the quite stable $\mathrm{K}$ and Ca content at $9 \mathrm{mM} \mathrm{S}$ and the similar increase in their content at $6 \mathrm{mM} \mathrm{S}$. The significantly higher root $\mathrm{Ca} / \mathrm{Mg}$ ratio in the plants supplemented with high levels of S, compared to those grown under conditions of the standard $\mathrm{S}$ level, was a consequence of the significant increase in the $\mathrm{Ca}$ content together with the unchanged (at $6 \mathrm{mM} \mathrm{S}$ ) or decreased (at $9 \mathrm{mM} \mathrm{S}$ ) $\mathrm{Mg}$ content. Simultaneously, the quite stable value of the shoot $\mathrm{Ca} / \mathrm{Mg}$ ratio resulted from the slightly changed $\mathrm{Ca}$ and $\mathrm{Mg}$ content. In all experimental treatments, the value of the $\mathrm{Ca} / \mathrm{P}$ ratio in aboveground wheat parts oscillated around the optimal value, which is 1 (Grzegorczyk and Gołebiewska 2004). Under the conditions of high $\mathrm{S}$ supplementation, irrespective of the Ni dose in the nutrient solution, the higher root $\mathrm{Ca} / \mathrm{P}$ ratio recorded was related to the significant rise in $\mathrm{Ca}$ and the slight changes in the $\mathrm{P}$ content. In turn, the lower shoot $\mathrm{Ca} / \mathrm{P}$ ratio in the treatments of the high $\mathrm{S}$ dose was a consequence of the increase in the $\mathrm{P}$ content together with the quite stable $\mathrm{Ca}$ content. It is generally recognized that the value of the N/S ratio indicates the status of S supply to plants. Such a statement is based on the fact that the vegetative organs of almost all crop plant species are characterized by quite a similar N/S value, which is $15: 1$ and the 10-15:1 range of this ratio is considered optimal (Blake-Kalff et al. 2000; Jez 2008; Jamal et al. 2010). The value of the N/S ratio recorded in the presented studies for wheat shoots oscillated in the range from 2.73 to 4.89 and the calculated average value of this ratio was 3.80. All of them are clearly lower than the above-mentioned value of the N/S ratio recognized as optimal. Some researchers do not share the view that the N/S ratio is a reliable diagnostic tool for evaluating the $S$ supply status. Their statement is based on the conviction that the surplus of one nutrient may be faultily interpreted as deficiency of another one, since a similar value of the ratio between two elements may be obtained at their completely different concentrations in the biomass. The results obtained in the presented studies show that high $\mathrm{S}$ supplementation significantly increases the wheat root N/S ratio due to a greater increase in the $\mathrm{N}$ than $\mathrm{S}$ content. In turn, the lower shoot N/S ratio was a consequence of the greater increase in the $\mathrm{S}$ than $\mathrm{N}$ content, whereas the changes in the $\mathrm{N}$ content under the highest $\mathrm{S}$ dose $(9 \mathrm{mM})$ used in the experiment were insignificant. It is well documented that the $\mathrm{N}$ content in plant biomass increases with additional application of both $\mathrm{N}$ and $\mathrm{S}$ within a narrow range of the N/S ratio for optimum crop yield and quality (Jamal et al. 2010; Choong and Choong 2013). Our studies revealed that such a tendency was also true for the $\mathrm{Ni}$ treated wheat intensive fertilized with $\mathrm{S}$.

\section{Dry biomass and nickel accumulation}

Our studies revealed that under the standard S dose $(2 \mathrm{mM})$, $\mathrm{Ni}$ accumulation in the spring wheat cv. Zebra biomass increased together with the increasing concentration of this element in the nutrient medium. We also showed that the increase in Ni accumulation was much more pronounced in shoots than in roots, which led to more severe inhibition of growth and a decrease of shoot biomass than roots. Likewise in our study, a similar pattern of Ni distribution and accumulation in aboveand underground parts of wheat as well as reduction of their growth was found by Kassim et al. (2013). Opposite trends were shown by Gajewska and Skłodowska (2008), Wang et al. (2009), Nafees and Amin (2014), and Stanišić Stojić et al. (2014). It should be stressed that by analyzing above- and underground parts of wheat, the contents of $\mathrm{Ni}$ (data in press) in Ni-stressed plants were much higher than the permissible limit of $2 \mathrm{mg} \mathrm{kg}^{-1}$ (Nafees and Amin 2014). It is well documented that growth inhibition and reduced dry biomass in the presence of $\mathrm{Ni}$ in the nutrient solution was a consequence of many processes, inter alia, changes in polysaccharides synthesis and carbohydrates translocation from shoots to roots (Kopittke et al. 2007); damage to the Golgi apparatus; changes in the ultrastructure of chloroplasts: disturbances in redox homeostasis; damage to DNA and RNA, proteins, and lipids; impaired cell divisions; suppression of cell elongation, e.g., via peroxidase activity stimulation; as well as disturbances in meristematic tissue differentiation and reduced intracellular species (Demchenko et al. 2005, 2010; Maksimović et al. 2007; Hansh and Mendel 2009; Jain et al. 2009; 
Kozhevnikova et al. 2009; Mesjasz-Przybyłowicz et al. 2010; Kumar et al. 2012; Parmar et al. 2012; Gopal 2014; Li et al. 2015). Also, our results (data in press) indicated increased superoxide anion radical $\left(\mathrm{O}_{2}{ }^{-}\right)$and hydrogen peroxide $\left(\mathrm{H}_{2} \mathrm{O}_{2}\right)$ accumulation together with increased lipid peroxidation as the causes of suppressed root elongation.

Our studies revealed that $\mathrm{Ni}$ accumulation in wheat was determined by the concentration of this element in the nutrient solution as well as the $\mathrm{S}$ level and varied for the particular organs. Increased bioaccumulation of $\mathrm{Ni}$ in roots and shoots of wheat grown in the Ni-contaminated nutrient medium supplied with the $6 \mathrm{mM} \mathrm{S}$ level resulted from the greater increase in the biomass rather than the decrease in $\mathrm{Ni}$ in the dry weight (data in press). The increase in root $\mathrm{Ni}$ accumulation in the treatment $0.04 \mathrm{mM} \mathrm{Ni} / 9 \mathrm{mM} \mathrm{S}$ was a consequence of the decreased Ni content and slight changes in the dry biomass. In turn, reduced $\mathrm{Ni}$ bioaccumulation in shoots of wheat stressed with high Ni doses and fertilized with $9 \mathrm{mM} \mathrm{S}$ resulted, to a great extent, from the decrease in the $\mathrm{Ni}$ content than the changes in dry biomass. In spite of the drop in the Ni content in the root and shoot biomass of plants treated with high $\mathrm{Ni}$ doses grown at $6 \mathrm{mM} \mathrm{S}$ as well as in roots at the treatment with $0.08 \mathrm{mM} \mathrm{Ni} / 9 \mathrm{mM} \mathrm{S}$, the Ni content in the biomass still exceeded the acceptable limits mentioned by Jabeen et al. (2010) (FAO/WHO standards), Shah et al. (2013), Nafees and Amin (2014), Nazir et al. (2015). However, the decrease in the Ni content corresponded with the increase in the organ biomass.

\section{Conclusion}

In conclusion, it can be claimed that Ni presence in the nutrient medium reduces the biomass and disturbs the balance and accumulation of macronutrients in spring wheat cv. Zebra. Intensive S nutrition, especially with $6 \mathrm{mM} \mathrm{S}$, at least partially increases the biomass, improves ionic equilibrium, and enhances nutrient accumulation in Ni-exposed plants in spite of increased $\mathrm{Ni}$ accumulation. Such an evident beneficial effect was not shown for the dose $9 \mathrm{mM} \mathrm{S}$. Admittedly, the dose $9 \mathrm{mM} \mathrm{S}$ reduced $\mathrm{Ni}$ accumulation in shoots but increased accumulation thereof in roots. Compared to $6 \mathrm{mM}$, the dose $9 \mathrm{mM}$ is less effective in improving the mineral status of the Ni-treated wheat. Both experimental intensive $\mathrm{S}$ doses $(6$ and $9 \mathrm{mM}$ ) resulted in an increased $\mathrm{N}$ and $\mathrm{S}$ content in root and shoots. A simultaneous drop in the $\mathrm{K}$ content in roots was shown and a rise in the $\mathrm{Ca}$ root content was recorded. Moreover, the dose $6 \mathrm{mM}$ increased the shoot $\mathrm{P}$ content, but $\mathrm{Mg} 9 \mathrm{mM}$ decreased the root $\mathrm{Mg}$ content. Given the promising results of the present study, further investigations concerning the influence of intensive $\mathrm{S}$ nutrition on metalstressed plants are recommended.
Acknowledgments This research was financially supported by the Polish Ministry of Science and Higher Education

\section{Compliance with ethical standards}

Conflict of interest The authors declare that they have no competing interest

Open Access This article is distributed under the terms of the Creative Commons Attribution 4.0 International License (http:// creativecommons.org/licenses/by/4.0/), which permits unrestricted use, distribution, and reproduction in any medium, provided you give appropriate credit to the original author(s) and the source, provide a link to the Creative Commons license, and indicate if changes were made.

\section{References}

Ahmad MSA, Ashraf M (2011) Essential roles and hazardous effect of nickel in plants. In: Whitacre DM (ed) Reviews of environmental contamination and toxicology. Springer, New York, Dordrecht Heidelberg, London, pp 125-167

Akhter N (2012) Comparison of DRIS and critical level approach for evaluating nutrition status of wheat in district Hyderabad, Pakistan. PhD Thesis. Bonn, Univ, Diss, 2011, pp 1-115

Aydinalp C, Marinova S (2003) Distribution and forms of heavy metals in some agricultural soils. Pol J Environ Stud 12(5):629-633

Bessa LA, Silva FG, Moireira MA, Teodoro JPR, Soares FAL (2013) Growth and nutrient accumulation in Anacardium othonianum Rizz. seedlings grown in nutrient solution. Chil J Agric Res 73(3): 301-308. doi:10.4067/S0718-58392013000300014

Bhatia NP, Walsh KB, Baker AJM (2005) Detection and quantification of ligands involved in nickel detoxification in a herbaceous $\mathrm{Ni}$ hyperaccumulator Stackhousia tryonii Bailey. J Exp Bot 56(415): 1343-1349. doi:10.1093/jxb/eri135

Blake-Kalff MMA, Hawkesford MJ, Zhao FJ, McGrath SP (2000) Diagnosing sulfur deficiency in field-grown oilseed rape (Brassica napus L.) and wheat (Triticum aestivum L.). Plant Soil 225(1-2):95107. doi:10.1023/A:1026503812267

Brown PH (2007) Nickel. In: Barker AV, Pilbeam DJ (eds) Handbook of plant nutrition. Taylor \& Francis Group, LCC, Boca Raton, London, New York, pp 395-410

Cempel M, Nikel G (2006) Nickel: a review of its sources and environmental toxicology. Pol J Environ Stud 15(3):375-382

Chen C, Huang D, Liu J (2009) Functions and toxicity of nickel in plants: recent advances and future prospects. Clean 37(4-5):304-313. doi: 10.1002/clen.200800199

Choong CW, Choong SM (2013) Optimum nitrogen to sulfur ratio to increase in vitro seedling yield of Phanaleopsis bellina. Int $\mathrm{J}$ Chem Environ Biol Sci 1(5):769-770

da Silva JA, Naeem M, Idrees M (2012a) Beneficial and toxic effects of nickel in relation to medicinal and aromatic plants. Med Aromatic Plant Sci Biotech 6(Special Issue 1)):94-104

de Kok LJ, Stulen I, Hawkesford MJ (2011) Sulfur nutrition in crop plants. In: Hawkesford MJ, Barraclough P (eds) The molecular and physiological basis of nutrient use efficiency in crops. WileyBlackwell, Oxford, pp 295-309. doi:10.1002/9780470960707.ch14

Demchenko NP, Kalimova IB, Demchenko KM (2005) Effect of nickel on growth, proliferation, and differentiation of root cells in Triticum aestivum seedlings. Russ J Plant Physiol 52(2):220-228. doi:10. 1007/s11183-005-0034-5 
Demchenko NP, Kalimova IB, Demchenko KN (2010) Effect of nickel at high concentration on proliferation of quiescent center cells and initiation of lateral root promordia in wheat seedlings. Russ J Plant Physiol 57(3):438-447. doi:10.1134/S1021443710030179/

Droux M (2004) Sulfur assimilation and the role of sulfur in plant metabolism: a survey. Photosyn Res 79(3):331-348. doi:10.1023/ B:PRES.0000017196.95499.11

da Silva JAT, Naeem M, Idrees M (2012b) Beneficial and toxic effects of nickel in relation to medicinal and aromatic plants. Med Aromatic Plant Sci Biotechnol 6(Special Issue 1):94-104

Ernst WHO, Krauss GJ, Verkleij JAC, Wesenberg D (2008) Interaction of heavy metals with the sulphur metabolism in angiosperms from an ecological point of view. Plant Cell Environ 31:123-143. doi:10. $1111 / j .1365-3040.2007 .01746 . x$

Fageira NK (2008) The use of nutrients in crop plants. Taylor \& Francis Group, Boca Raton, p 448

Gaillardet J, Viers J, Dupré B (2005) Trace elements in river waters. In: Drever JI (ed) Surface and ground water, weathering and soils. Treatise on Geochemistry, Oxford, Elsevier 5:225-227

Gajewska E, Skłodowska M (2008) Differential biochemical responses of wheat shoots and roots to nickel stress: antioxidative reactions and proline accumulation. Plant Growth Regul 54(2):179-188. doi:10. 1007/s10725-007-9240-9

Gill SS, Tuteja N (2011) Cadmium stress tolerance in crop plants. Probing the role of sulfur. Plant Signal Behav 6(2):215-222. doi:10.4161/ psb.6.2.14880

Gopal R (2014) Excess nickel modulates oxidative stress responsive enzymes in groundnut. J Plant Nutr 37(9):1433-1440. doi:10.1080/ 01904167.2014.881872

Gospodarek J, Nadgórska-Socha A (2010) Comparison of the effect of liming and magnesium treatment of heavy metal contaminated soil on the content of magnesium, calcium and iron in broad bens (Vicia faba L. spp. Major). J Elem 15(1):81-88. doi:10.5601/jelem.2010. 15.1.81-88

Grzegorczyk S, Gołebiewska A (2004) Content of some mineral components in Lolium perenne L. and Festuca pratensis L. cultivated in pure sowing and in mixtures with Plantago lanceolata L. (in Polish). Ann Univ Mariae Curie-Skłodowska, E Agric 59(1):457-460

Hansh R, Mendel RR (2009) Physiological functions of mineral micronutrients $(\mathrm{Cu}, \mathrm{Zn}, \mathrm{Mn}, \mathrm{Fe}, \mathrm{Ni}, \mathrm{Mo}, \mathrm{B}, \mathrm{Cl})$. Curr Opin Biotech 12(3):59-266. oi:10.1016/j.pbi.2009.05.006

Hawkesford MJ, De Kok LJ (2006) Managing sulphur metabolism in plants. Plant Cell Environ 29(3):382-395. doi:10.1111/j.13653040.2005.01470.x

Hussain MB, Ali S, Azam A, Hina S, Ahsan M, Farooq BA, Bharwana SA, Gill MB (2013) Morphological, physiological and biochemical responses of plants to nickel stress: A review. Afr J Agric Sci 8(17): 1596- 1602. doi:10.5897/AJAR12.407

Hossain MA, Piyatida P, Texteira da Silva JA, Fujita M (2012) Molecular mechanism of heavy metal toxicity and tolerance in plants: central role of glutathione in detoxification of Reactive Oxygen Species and methylglyoxal and in heavy metal chelation. J Bot:1-37. http:// dx.doi.org/10.1155/2012/872875

Iyaka AY (2011) Nickel in soils: a review of its distribution and impacts. Scienti Res Ess 6(33):6774-6777. doi:10.5897/SREX11.035

Jabeen S, Shall MT, Khan S, Hayat MQ (2010) Determination of major and trace elements in ten important falk therapeutic of Hanpur Basin. J Med Plants Res 4(7):559-566

Jain R, Srivastava S, Shrivastava AK (2009) Changes in growth, cell division and metabolism of sugarcane in response to nickel. Trop Med 86(4):128-133

Jamal A, Moon YS, Abdin MZ (2010) Sulphur - a general overview and interaction with nitrogen. Aust J Crop Sci 4(7):523-529

Janicka-Russak M, Kabała K, Burzyński M, Kłobus G (2008) Response of plasma membrane $\mathrm{H}^{+}$-ATPase to heavy metal stress in Cucumis sativus roots. J Exp Bot 59(13):3721- 3728. doi: 10.1093/jxb/ern219
Jez J (2008) Sulfur: a missing link between soils, crops, and nutrition. Agronomy Monography 50, United States of America Publisher: American Society of Agronomy, Crop Science Society of America, Soil Science Society of America, pp 335

Kabata-Pendias A, Mukherjee AB (2007) Trace elements from soil to human. Springer, New York, Berlin, Heidelberg, p 550. doi:10. 1007/978-3-540-32714-1

Kassim JK, Kareem MI, Mohammed ZK (2013) Ni, Co, Cr and Mn metals uptake by wheat and grass plants from serpentinic soils of Penjwin, Kurdistan Region-Iraq. Int J Pl An Env Sci 3(2):76-84

Khan NA, Singh S, Umar S (2008) Sulphur assimilation and abiotic stress in plants. Springer, Berlin, Heidelberg, p 372. doi:10.1007/978-3540-76326-0

Kopittke PM, Asher CJ, Menzies NW (2007) The effects on $\mathrm{Ni}^{2+}$ on growth of cowpea (Vigna unguiculata). Plant Soil 292(1-2):283289. doi:10.1007/s11104-007-9226-4

Kopriva S (2007) Sulfur metabolism in plants. eLS John Willey \& Sons Ltd, Chichester. http://www.els.net [doi: 10.1002/9780470015902. a0020126]

Kozhevnikova AD, Seregin IV, Bystrova EI, Belyaeva AI, Kataeva MN, Ivanov VB (2009) The effect of lead, nickel, and strontium nitrates on cell division and elongation in maize roots. Russ J Plant Physiol 56(2):242-250. doi:10.1134/S1021443709020137

Kozlow MV (2005) Pollution resistance of mountain birch, Betulapubescens subsp. czerepanovii, near the copper-nickel smelter: natural selection or phenotypic acclimation. Chemosphere 59(2):189-197

Kucharski J, Boros E, Wyszkowska J (2009) Biochemical activity of nickel-contaminated soil. Pol J Environ Stud 18(6):1039-1044

Kumar H, Sharma D, Kumar V (2012) Nickel-induced oxidative stress and role of antioxidant-defence in barley roots and leaves. Intern $\mathrm{J}$ Environ Biol 2(3):121-128. doi:10.1007/s10725-009-9386-8

Küpper H, Lombi E, Zhao FJ, Wieshammer G, McGrath SP (2001) Cellular compartmentation of nickel in the hyperaccumulators Alyssum lesbiacum, Alyssum bertolonii and Thlaspi goesingense. J Exp Bot 52:2291-3000. doi:10.1093/jexbot/52.365.2291

Lander MS (2003) Evaluation of selected heavy metal concentrations in soils of an urban stormwater retention basin. University of Florida, MS thesis, $\mathrm{p} 145$

Leitenmaier B, Küpper H (2013) Compartmentation and complexation of metals in hyperaccumulators plants. Front Plant Sci 4:374 \# 13. doi: 10.3389/fpts.2013.00374

Li Z, Chen X, Li S, Wang Z (2015) Effect of nickel chloride on Arabidopsis genomic DNA and methylation of $18 \mathrm{~S}$ rDNA. Electron J Biotechn 18(1):51-57. doi:10.1016/j.ejbt.2014.12.004

Liu GD, Simonne EH, Li Y (2011) Nickel nutrition in plants. Gainesville: University of Florida: Institute of Food and Agricultural Sciences, http://edis.ifas.ufl.edu (Access:15.04.2015)

López MA, Magnitski S (2011) Nickel: The last of the essential micronutrients. Agron Colom 29:1-9

Maksimović I, Kastori R, Kristić L, Luković J (2007) Steady presence of cadmium and nickel affects root anatomy, accumulation and distribution of essentials ions in maize seedlings. Biol Plantarum 51(3): 589-592. doi:10.1007/s10535-007-0129-2

Mazid M, Khan TA, Mohammad F (2011a) Response of crop plants under sulphur stress tolerance: a holistic approach. J Stress Physiol Biochem 7(3):23-57

Mazid M, Khan ZH, Quddusi S, Khan TA, Mohammad F (2011b) Significance of sulphur nutrition against metal induced oxidative stress in plants. J Stress Physiol Biochem 7(3):165-184

Mazzafera P, Tezotto T, Polacco JC (2013) Nickel in plants. In: Kretsinger RH, Uversky VN, Permyakov EA (eds) Encyclopedia of Metalloproteins. Springer, New York, pp 1496-1501. doi:10.1007/ 978-1-4614-1533-6_87

Mašauskiene A, Mašauskas V (2012) Soil sulphur problems and management. In: Jakobsson Ch (ed) Sustainable agriculture ecosystem 
health and sustainable agriculture. Book 1, Uppsala, Baltic University Press, pp 113-145

Mesjasz-Przybyłowicz, J.A., Barnabas, A.D. \& Przybyłowicz W. 2010. Comparison of anatomy, cytology and distribution of nickel in leaves of Ni-hyperaccumulating and non-hyperaccumulating Barkheya zeyheri. Available on line at: https://microscopy.org/ MandM/2010/barnabas.pdf

Morgan JB, Connolly EL (2013) Plant-soil interactions: nutrient uptake. Nature Educ Know 4(8):2

Nafees M, Amin A (2014) Evaluation of heavy metals accumulation in different parts of wheat plant grown on soil amended with sediment collected from Kabul river canal. J Agric Res 52(3):383-394

Nazir R, Khan M, Masab M, Rehman HU, Rauf NU, Shahab S, Ameer N, Sajed M, Ullah M, Rafeeq M, Shaheen Z (2015) Accumulation of heavy metals $(\mathrm{Ni}, \mathrm{Cu}, \mathrm{Cd}, \mathrm{Cr}, \mathrm{Pb}, \mathrm{Zn}, \mathrm{Fe})$ in the soil, water and plants and analysis of physic-chemical parameters of soil and water collected from Tanda Dam koh at. J Pharm Sci Res 7(3):89-97

Osu CI, Isaac IU (2014) Effect of nickel concentrations on Amaranthus spinosus uptake of nutrients and heavy metals in soil. J Appl Phytotechnol Environ Sanit 3(3):87-91

Parmar P, Patel MJ, Dave B, Subramanian RB (2012) Nickel accumulation by Colocassia esculentum and its impact on plant growth and metabolism. Afr J Agric Res 7(24):3579-3587. doi:10.5897/ AJAR11.1914

Pereira BFF, Rozane DE, Araújo SR, Barth G, Queiroz RJB, Nogueira TAR, Moraes MF, Cabral CP, Boaretto AE, Malavolta E (2011) Cadmium availability and accumulation by lettuce and rice. Rev Bras de Cienc Solo 35(2):645-654. http://dx.doi.org/10.1590/ S0100-06832011000200033

Polish National List of Agricultural Plant Varieties (2012). (in Polish: Lista odmian roślin rolniczych wpisanych do krajowego rejestru w Polsce). Centralny Ośrodek Badania Odmian Roślin Uprawnych. Słupia Wielka, pp 78

Pollard AJ, Powell KD, Harper HA, Smith JAC (2002) The genetic basis of metal hyperaccumulation in plants. Crit Rev Plant Sci 21(6):539 566. doi:10.1080/0735-260291044359

Poonkothai M, Vijayavathi BS (2012) Nickel as an essential element and a toxicant. Int J Environ Sci 1(4):285-288

Ragsdale SW (2009) Nickel-based enzymatic systems. J Biol Chem 284: 18571-18575. doi:10.1074/jbc.R900020200

Rubio MI, Escri I, Martinez-Cortina C, López-Benet J, Sanz A (1994) Cadmium and nickel accumulation in rice plants. Effects on mineral nutrition of abscisic acid and gibberellic acids. Plant Growth Regul 14(2):151-157. doi:10.1007/BF00025217
Sanz A, Llamas A, Ullrich CI (2009) Distintive phytotoxic effect of Cd and $\mathrm{Ni}$ on membrane functionality. Plant Signal Behav 4(10):980 982. doi:10.1016/j.plaphy.2008.05.006

Seregin IV, Kozhevnikova AD (2006) Physiological role of nickel and its toxic effects on higher plants. Russ J Plant Physiol 53(2):257-277. doi:10.1134/S1021443706020178

Shah A, Niaz A, Ullah N, Rehman A, Akhlaq M, Khan MS (2013) Comparative study of heavy metals in soil and selected medicinal plants. J Chem 2013(3013), \#5. Article ID 621265. doi: 10.1155/ 2013/621265

Sharma A, Dhiman A (2013) Nickel and cadmium toxicity in plants. J Pharm Sci Innov 2(2):20-24. doi:10.7897/2277-4572.02213

Sigel A, Sigel H, Sigel RKO (2007) Nickel and its surprising impact in nature: metal ions in life sciences. Willey \& Sons, West Sussex, England, p 728

Sreekanth TVM, Nagajyothi PC, Lee KD, Prasad TNVKV (2013) Occurrence, physiological responses and toxicity of nickel in plants. Intern J Environ Sci Techn 10(5):1129-1140. doi:10.1007/s1362013-0245-9

Stanišić Stojić SM, Ignjatović LM, Popov S, Škrivanj S, DorDević AR, Stojić A (2014) Heavy metal accumulation in wheat and barley: the effects of soil presence and liquid manure amendment. Plant Biosyst An Int J Deal with all Asp Plant Biol. doi:10.1080/11263504.2014. 976288

Starast M, Karp K, Vool E (2007) Effect of NPK fertilization and elemental sulphur on growth and yield of lowbush blueberry. Agric Food Sci 16(1):34-45. doi:10.2137/145960607781635859

Viehweger K (2014) How plants cope with heavy metals. Bot Stud 55(35): 1 - 12. \#12 doi: 10.1186/1999-3110-55-35

Wang S, Nan Z, Liu X, Qin S, Ding H (2009) Accumulation and bioavailability of copper and nickel in wheat plants grown in contaminated soils from the oasis, northwest China. Geoderma 152(3-4): 290-295. doi:10.1016/j/geoderma.2009.06.012

Wuana RA, Okieimen FE (2011) Heavy metals in contaminated soils: a review of sources, chemistry, risks and best available strategies for remediation. ISRN Ecology 2011:1-20. doi:10.5402/2011/402647

Yusuf M, Fariduddin Q, Hayat S, Ahmad A (2011) Nickel: an overview of uptake, essentiality and toxicity in plants. Bull Environ Contam Toxicol 86(1):1-17. doi:10.1007/s00128-010-0171-1

Zagorchev L, Seal CE, Kranner I, Odjakova M (2013) A central role for thiols in plant tolerance to abiotic stress. Int J Mol Sci 14(4):74057432. doi:10.3390/ijms14047405 